\title{
Adoption Of Macroprudential Policy In An Inflationary Economy: Implication For Developing Economies
}

\author{
${ }^{1}$ Augustine Ujunwa, ${ }^{2}$ Ifeoma Nwakoby, ${ }^{3}$ Chinwe Okoyeuzu \\ Department of Banking and Finance, University of Nigeria Enugu Campus, \\ Enugu State, Nigeria. \\ ${ }^{1}$ E-mail: austinesilver@yahoo.com \\ 2E-mail: ifekoby@yahoo.com \\ ${ }^{3}$ E-mail: chinwe.okoyeuzu@unn.edu.ng
}

\begin{abstract}
Purpose: The purpose of this paper is to critique the suitability of macro prudential policy as a proactive and effective toolkit for mitigating financial system risk in developing economies.

Design/methodology/approach: The author first discusses the causes of the 2007/2008 global financial crisis in developed and developing economies. The narration is to demonstrate that the causes, duration and amplitude of the crisis differ across jurisdictions, and any regulatory model that will be effective in mitigating future crises must take into cognizance the institutional peculiarities of those countries.
\end{abstract}

Findings: The paper provides evidence on the difficulties of implementing the macro-prudential policy toolkits in developing economies because of their institutional and structural characteristics such as inflationary pressure, undiversified economy, lagging supervision, among others.

Research Limitations/implication: There is paucity of substantial local literature on macro-prudential policy in developing economies, especially Africa. While this study is meant to close this gap, literature reviewed however, relied extensively on studies on developed economies.

Practical implication: The extrapolation of prudential tools from developed economies requires serious caution by developing economies because of dissimilarities in economic structure, financial system, governance structure and causes of systemic risk, which may not be mitigated by macro-prudential toolkits.

Originality and Value: The study adds value to the global discourse on regulatory models for mitigating systemic crisis by introducing the perspective of developing economies to the macro-prudential debate.

\section{Keywords}

Global Financial Crisis, Macro-prudential Policy, Micro-prudential Policy, Systemic Risk, Developing Economies, Nigeria

\section{Council for Innovative Research}

Peer Review Research Publishing System

\section{Journal: International Journal of Management \& Information Technology}

Vol. 8, No. 2

editor@cirworld.com

www.cirworld.com, member.cirworld.com 


\section{INTRODUCTION}

The 2007/2008 global financial crisis, which triggered distressed assets, high bank insolvency and loss of market trust in developed economies, threatened large-scale private sector defaults in emerging economies (IMF, 2009), and is still ravaging the entire architecture of the global financial system, has an elicited plethora of research interest among practitioners and scholars. These studies cover a broad range of topics such as the causes of the crisis (Hampel, Schenk and Rick, 2008), effects of the crisis on macroeconomic environment, the role of the crisis in changing market fundamental across countries, and policy responses (IMF, 2009; Asia Development Bank, 2009). The growing consensus among practitioners and scholars is that monetary and fiscal policy tools would not have mitigated the crisis ${ }^{1}$, and as such, they attributed inadequacy in regulatory tools to be the prime cause of the crisis. Specifically, Galati and Moessener (2011) summarized the situation thus: "the recent financial crisis has highlighted the lack of analytical frameworks to help predict and cope with the global build-up of financial imbalances whose sudden unwinding turned out to have severe macroeconomic consequence... In terms of policy, the recent financial crisis has highlighted the need to go beyond a micro-based approach to financial regulation and supervision".

As a follow-up to this finding, financial system regulators are advocating for a more robust regulatory framework for the global financial system that reflects the broad lessons learnt from the current crisis, with the analytical spotlight on reshaping the international financial system, restructuring its governance architecture and enshrining a stable and stress resisting global financial system. This is based on lessons from the crisis which scholars and regulators claimed to have revealed the inadequacy of traditional tools and policies ${ }^{2}$ (fiscal and monetary policies) in coping with, or curbing the crisis. The intensity, duration and severity of the crisis, especially in developed economies, has brought to the fore the urgent need to rethink financial system regulation with emphasis on proactive and effective systemic risk mitigating regulatory model. This has resulted in the taxonomy 'macro prudential policy' championed by financial regulators in developed economies such as the Bank for International Settlement, European Central Bank and the Bank of England, among others.

These institutions have also designed macro prudential toolkits which could be broadly categorized into balance sheet tools, tools that influence terms and conditions of new lending and market structure tools. These institutions are also persuading developed and developing economies to adopt the macro prudential policy as an important toolkit for promoting financial system stability ${ }^{3}$. In Africa for example, different Central Banks are currently converging to the use of macro prudential policy framework which relies entirely on tools developed based on lessons learned from developed economies. Importantly, most macro prudential policy toolkits which formed the bedrock of major discussions were developed by multi-lateral institutions like International Monetary Fund (IMF), Bank for International Settlement (BIS) and Financial Stability Board (FSB) at the instance of G-20 and G-30, and financial regulators in developed economies such as the Bank of England.

This raises important research and policy questions on the suitability of these tools for developing economies, given the differences in their financial architecture, such as the causes, duration and amplitude of the crisis ${ }^{4}$, the structure of the financial system, effectiveness of regulation, and stability of aggregate economic indicators. Claessens and Ghosh (2012) captured the differences in developing and developed financial system thus: "the magnitude of financial shocks faced by developing economies-both positive and negative-is often large relative to their domestic economy and size and depth of the financial sector... Developing economies markets are more prone to external shocks in part because their economies are often less diversified in structure... Financial sector in most [developing economies] markets are bank dominated... More broadly, shocks tend to get amplified and propagated more easily in [developing economies] due to their structural and institutional characteristics".

\footnotetext{
${ }^{1}$ Financial system regulators in developed economies are asserting with strong conviction that the existing monetary and fiscal policy tools could not have contained the crisis. For instance, they argue that one of the causes of the crisis was the low interest rate which prevailed in many countries at that time. They however doubted whether a tighter monetary policy would have mitigated the crisis without dragging the countries into recession.

\begin{abstract}
${ }^{2}$ In the opinion of Ekholm (2012), though the role of monetary policy in averting financial crisis cannot be relegated to the shadows, it appears unreasonable to assume monetary policy could have averted the crisis on its own. On fiscal policy, she was explicit in stating that "stricter budget discipline would probably have counteracted overheating in some European countries, but it could not of course have averted the financial crisis which was largely imported".

${ }^{3}$ The first major study on Macro prudential Policy was commissioned by G20 with Tiff Macklem and Rakesh Mohan as co-chairs and they submitted their report in March/April 2009. The second report was at the instance of the International Centre for Monetary and Banking Studies and the Centre for Economic Policy Research which is christened the eleventh Geneva Report. The committee on the Global Financial System also intensified its research on Macro prudential Policy by publishing "The role of Valuation and leverage in procyclicality" in April 2009, "The role of margin requirements and haircuts in procyclicality" in March 2010 and "Macro prudential instruments and frameworks: a stocktaking of issues and experiences in May 2010 (for details, see Longworth, 2011). G20 demonstrated strong support for Macro prudential policy initiative by establishing Macro prudential authorities and encouraged emerging economies to follow their examples.
\end{abstract}

\footnotetext{
${ }^{4}$ Arnold, Borio, Elllis and Moshirian (forthcoming) argue that "the amplitude and length of financial cycle are regime dependent" and "do not reflect by any means natural constants".
} 
To shed light on these questions, this paper seeks to evaluate the suitability of adopting macro prudential policy in developing economies using Nigeria as a case study, while placing the analytical spotlight on the lessons learned from the crisis and the exigency of realigning national policy objectives with the worrisome global trend. The paper begins with a discussion of the causes of the global financial crisis, and focuses on negative externalities (imported shocks) and lagging supervision (inability of regulatory authorities to ensure financial system stability) as the transmission channels of the crisis in Nigeria, and not the inadequacy of micro prudential tools. The paper goes on to analyse the macro prudential tools, particularly the countercyclical capital buffer; that is, highlighting the difficulties of implementing such recommendations in an inflationary economy. The paper next situates the important lessons learned from the 2007/2008 global financial crisis, with an emphasis on policy initiatives that would prevent developing countries from relapsing into further crisis in the near future.

\section{CAUSES OF THE GLOBAL FINANCIAL CRISIS}

The 2007/2008 global financial crisis that ravaged the financial architecture of the world has elicited so much interest among practitioners and scholars, especially on the strategy for preventing future occurrence and ensuring financial system stability. The crisis which was triggered by the sub-prime mortgage crisis in United States of America, before spreading to Europe, Asia, and other countries of the world has been described as a 'tsunami' in order to properly capture its magnitude and peculiarity in terms of origin, evolution, nature, pace and the disturbing realities (Chossudovsky, 2009). The world blamed the United States subprime mortgage as the prime cause of the crisis. Gupta, et al., (2010) supports this view by arguing that "the subprime mortgage is designed to cater for customers that are unable to meet documentation requirements for ordinary mortgage". This reveals the risky nature of subprime lending when compared to normal lending and more importantly, the wisdom in banks staying away from this segment due to high default risk. In the 1990s, the segment witnessed serious boom due to factors such as; housing price appreciation; reduction in risk horizon for original mortgage lender (securitization); lax lending standards (a corollary of the securitization, which is the ability of lenders to push-off loans from their books to the financial markets); low interest rates, abundant liquidity and a chase for yield; and adjustable rate of mortgages and teaser rates (Gupta et al., (2010). An ever increasing number of banks also intensified their lending to the sector till the burst in 2007, that is, the monumental slide in housing prices

Though, subprime mortgage is usually cited as the proximate cause, the remote causes of the financial crisis have been attributed to many factors. Uche (2009) linked the origin of the crisis to the unwillingness of financial regulators to learn from the 1929 financial crisis. He argued that the abolition of the Glass Steagall Act of 1933 (Banking Act of 1933) which separated banking from securities business to eliminate all areas of potential conflict of interest that could arise as a result of combining commercial banking with investment banking, and the enactment of the Gramm-Leach-Bliley Act (BLBA) of $1999^{5}$, which effectively repealed the prohibition of combining banking and securities business triggered the crisis. He summarized his argument thus: "...because of the sheer size of the American financial system, once the Glass Steagall obstruction was eliminated, it quickly established itself as the champion of the transition from a bank-based system of financial intermediation to a credit-market based system. Under the new system, the practice of securitization of assets reigned supreme. Problem assets were simply securitized through complex models and transferred to third parties with the aid of Special Purpose Vehicles (SPVs). This effectively removed such assets from the balance sheet of the financial institutions that originated them. This was the very foundation of the US subprime mortgages which is at the centre of the current financial crisis".

The abolition of the Glass Steagall Act of 1933 eliminated all barriers in terms of banks combining non-bank financia services (universal bank) and banking services ${ }^{6}$. This banking model encouraged large correlated holdings by banks, development of capital-market based securities, promotion of shadow banking, complex network of contracts, and asset price bubble which were part of the build-up to the crisis.

Scholars and practitioners also blamed the crisis on the liberalisation of the financial system. Financial liberalisation ${ }^{7}$ is an operational reform and policy measure designed to deregulate the financial system within an appropriate regulatory framework. The argument is that financial liberalisation accelerated unregulated international investment funds as a result of the global abolition of restrictions on capital flow. This is based on the global savings glut theory, which postulates that the massive flow of savings from surplus countries to deficit countries lowered global interest rates by encouraging

\footnotetext{
${ }^{5}$ For details on the origin and forces behind the Gramm-Leach Bliley Act, see Uche (2009)

${ }^{6}$ Uche (2001) identified the potential conflicts of interest in universal banking scheme to include; granting imprudent loans to issuers of securities underwritten by an affiliate; granting risky loans to separately capitalized securities of affiliates in financial difficulty; granting of loans in order to support the price of a security issued by affiliate.; the placement of unsold securities in a bank's trust account; conflict between the commercial banker's obligation to provide impartial advice to depositors and promotional role of investment bankers; banks may also blackmail their customers to use their underwriting services.
}

\footnotetext{
${ }^{7}$ The role of financial liberalization in economic growth thesis propounded by McKinnon (1973) and Shaw (1973) have come under serious scrutiny recently. This current focus is accentuated because of two factors. First is the apparent inability of the classical and neoclassical models to adequately address the global financial crisis which ravaged the economies of the world. Second is the decision by the governments of developed and developing economies to move conveniently away from free market fundamentals, to a regulated economy regime, with the governments taking up major stakes in the financial markets through the injection of funds as measures of curbing the global financial crisis.
} 
reckless investment into risky housing-related assets such as subprime mortgages. The global savings glut theory lends further support to the notion that global imbalances are unsustainable and their unwinding will necessarily be disruptive (Adams and Park, 2009)

The level of speculation in the financial system is another factor that is linked to the crisis. Most practitioners blamed the crisis on the United States housing policy which encouraged low-income earners to own houses. Ekholim (2012) brings this to the fore by asserting that "the United States deficiencies in the regulation of the mortgage market and a housing policy that promoted homeownership among low-income-owners were more prominent contributing factors." Recent revelations show a speculative dimension to this trend. For instance, while it is generally agreed that real estate is not an avenue for speculative investment, this was not the case in United States during the housing boom. It was reported that approximately $40 \%$ of home purchases were not for primary residences, but for speculative purposes and one of the factors that led to the drastic fall in housing prices.

Analysts have also identified the low interest rates that prevailed before the crisis in many countries as an important determinant of 'unsustainable increase in indebtedness and property prices'. This is premised on the fact that the combination of low interest rates and large inflows of foreign funds eased credit conditions, and made subprime lending and borrowing very attractive in US, UK and Sweden. These conditions, coupled with rising demand for housing, propelled investors to access mortgage loan for investment in houses.

The activities of rating agencies have also been identified as another cause of the crisis. In the wake of financial innovation and complex financial products (asset securitization) ${ }^{9}$ for instance, investors relied heavily on rating agencies, since they lacked the analytical and technical background based on the complex nature of those financial products. The credit rating agencies however, adopted the same credit risk metrics for all financial products. The uniform rating scale led to the underestimation of the systemic risk of structured products compared to corporate and sovereign bonds. This shows clearly the unpreparedness of rating agencies to adequately rate the structured products due to their complexities. Gupta et al., (2010) captured the role of rating agencies by arguing that "[Credit] ratings contributed in the flow of global investor funds into these securities, funding the housing bubble in the US. A total amount of $\$ 3.2$ trillion was the inflow on account of loans made to homeowners with doubtful creditworthiness between 2002 and 2007. These mortgages could be bundled into mortgage-backed securities (MBS) and collateral debt obligations (CDO) securities that received high ratings, and therefore could be sold to global investors. At the inception of the structuring process, the credit rating agencies took lower rated mortgage bonds combined with equity, to form a Mezzanine CDO to enable it to receive a higher rating. During the second stage, these intermediate rated (AA or BB-) Mezzanine CDO or normal CDOs were combined together again to form AAA rated securities. The rating agencies advised their clients on structuring the debt of the products thereby creating a chain of multilayered mortgage products and then, consequently rating them as AAA ratings. Thus, the products created at every stage carried more risk and illiquid securities than the previous ones, yet carried a rating of AAA. As mortgage securities became increasingly complex with little transparency on composition and characteristics of these loans held in the pools, investors relied more on the CRAs".

\footnotetext{
${ }^{8}$ Adams and Park (2009) argue that "[t]he existence of current imbalances is not a cause for concern. Given increasing financial integration across countries, there is no reason why countries should run balanced current position at all times. Nevertheless, the size and persistence of global imbalances, as well as their concentration in a small group of countries, have raised concern about their sustainability. There have also been questions on whether it is optimal for low-income developing countries to use their savings to finance the consumption of high-income countries and forgo productive investments.

${ }^{9}$ Gupta et al., (2010) argue that "to free up their capital in order to make fresh loans, mortgage banks started issuing mortgage backed securities (MBS) that is securities backed by pool of mortgaged loans made to home borrowers. Investors were keen to invest in such MBS as it provided them both yield and risk diversification. Wall Street firms then began to use these MBS as components for more complex structured products such as collateralized debt obligations (CDOs) which were essentially created by slicing and dicing the MBS into various tranches, each with a different level of risk and return. These collaterised debt obligation tranches were given credit ratings by the established credit rating agencies. Very often, the structuring of the product itself was done by the investment bank and the credit rating agency working together. These CDOs were then sold across the world to a cross-section of banks, mutual funds, pension funds, state bodies such as municipal organizations and a host of others... However, monetary policy had begun to tighten from 2004 when in order to control growing inflation the Federal Reserve raised its key short term interest rate. The Federal funds target rate shot up from $1 \%$ in 2004 to $5.25 \%$ by 2006 . In line with this, subprime lending rates too increased substantially, which adversely affected this segment's repayment capacity. Simultaneously the boom in U.S. housing prices faded out and housing prices started to actually fall. The above two factors led to a jump in payment defaults by the original borrowers in the subprime segment. But by then the U.S. mortgage backed- securities market (at $\$ 8$ trillion outstanding) had became the largest fixed-income market in the world, even bigger than the U.S. treasury market. As borrowers started defaulting, first the market prices of MBS fell, and then the values of CDOs began dropping too. Banks had to report large losses on account of the mark-to-market of their sizeable holdings of MBS and CDOs. Many mortgage lenders went bankrupt and large investment banks had to raise emergency capital. As their capital was eroded, they cut down on lending to maintain their capital adequacy ratio (CAR). The resulting liquidity crisis pushed the entire U.S. economy into a recession.
} 
The endorsement of these complex financial products by rating agencies ${ }^{10}$ boosted investors' confidence in the products which would have been very difficult if the acceptance of such products rested squarely on the ability of issuers to convince the investors on the viability and profitability of such product (Uche, 2009).

On the other hand, the causes of the crisis in developing economies are diametrically different. In Nigeria for instance, at the inception of the crisis, financial regulators argued that the Nigerian financial system was insulated from the global crisis, since the "economy draws its strength from strong internal dynamics rooted in its large population, resilient Small and Medium Enterprises, vibrant informal sector and excellent crop of entrepreneurs" (Ujunwa et al., 2011). Within the period also, the Central Bank of Nigeria conducted commercial bank audit which revealed the soundness of the Nigerian banking system in resisting external shocks. IMF within the period endorsed the strength of Nigerian banking system in supporting economic growth.

Despite these assurances from financial system regulators, the Nigerian stock market was not spared from the crisis. Ujunwa et al., (2011) noted that "while the regulators of Nigerian financial system were canvassing for a new economic model for the global financial crisis, Nigerian investors who were basking in the euphoria that the financial system was insulated from the global financial crisis were caught in the gap. For example, the Nigerian Stock Exchange that witnessed unprecedented growth in total market capitalization and value of shares traded for 2004 - early 2008, is currently experiencing a serious downturn in its activities. The market capitalization of the 303 listed equities., which had opened on January 1st, 2008, at N10.18th and later appreciated to N12.395th as at March 2008, suffered its highest fall in the 48year history of the Nigerian Stock Exchange, depreciating by N3.223tn or 32 per cent to N6.957tn by the year end. Similarly, the NSE All Share Index depreciated by the same margin from 63,016.60 at which it opened in January, to $31,450.78$ at the last trading day at 2008".

The banking system was not spared, but in view of the inaction of CBN at that time, it appeared to have weathered the storm because of the supposedly 'low-level of Nigerian banking system integration with the global financial system'. However, a review of the Expanded Discount Window in 2009 revealed that five banks were frequently using the window $^{11}$. The decision of the CBN to review the activities of banks in the expanded discount window was belated, as effective regulation would entail good knowledge of the extent of bank exposure prior to the crisis. Sanusi (2009a) noted that "an examination of the five banks revealed excessively high level of non-performing loans which is attributable to poor corporate governance practice. The total loan portfolio of these banks amounted to N2,801.92 billion ${ }^{12}$, the five banks accounted for a disproportionate component of the total exposure to capital market and oil and gas, the huge provisioning requirements have led to significant capital impairment, and the five banks were either the perennial net takers of funds in the inter-bank market or enjoyed support from the CBN for a very long time, a clear indication of illiquidity".

The revelation prompted the $\mathrm{CBN}$ to order a special examination of the remaining banks which further revealed that four additional banks were in a grave situation ${ }^{13}$. Aside the removal of the CEO of the affected banks, the CBN also injected N620 billion into the distressed banks in the form of tier two-capital. The crisis also crept into the revenue of the government as crude oil prices slid in the international market.

One key source of the amplification of the financial crisis in Nigeria is capital flows. From a theoretical and empirical view point, large capital inflows can promote macroeconomic vulnerabilities and stymie financial stability. This is even worse where the flow is in the form of portfolio investment (flows to the capital market) ${ }^{14}$, since it can indirectly promote financial

\footnotetext{
${ }^{10}$ The global financial crisis and the activities of rating agencies in fuelling the crisis have put rating agencies in the centre of vitriolic criticism. United States Securities and Exchange Commission (SEC) has also made some proposals on the direction to follow. For details see Gupta et al., (2010)

${ }^{11}$ It is important to state that this was the period within which the Federal Government of Nigeria appointed Sanusi Lamido Sanusi as the new Governor of Central Bank of Nigeria upon the expiration of the tenure of Charles Chukwuma Soludo. The affected banks were Afribank, Finbank, Intercontinental bank, Oceanic bank and Union bank. Ecobank acquired Oceanic bank in December, 2011, Access bank acquired Intercontinental bank in December 2011 and First City Monument bank acquired Fin bank on the $10^{\text {th }}$ of February 2012 Afribank is among the three banks which the Central Bank of Nigeria nationalised in August, 2011 and re-named Keystone bank.

${ }^{12}$ For instance, there was a bank audit by CBN before the crisis and the banks were given a clean bill of health. Six months after, another audit by the same CBN revealed the amount of delinquent loans for five banks to be N2.8 billion. The fact that delinquent loans are time dimensional raises an important question on whether these banks accumulated these non-performing loans after the first audit.

${ }^{13}$ The four banks were Bank PHP, Equitorial Trust Bank, Spring Bank and Wema Bank. Bank PHP and Spring bank were nationalized in August, 2011 and their names changed to Mainstreet bank and Enterprise bank respectively. In the same vein, Equitorial Trust Bank was acquired by Sterling Bank Plc in August, 2011.

${ }^{14}$ International Monetary Fund (1993) defines foreign portfolio investment as equity and debt issuances including country funds, depository receipts, and direct purchases by foreign investors of less than $10 \%$ control. This implies that the investor has no intention of participating in the management of the enterprise. Foreign portfolio investment, unlike foreign direct investment is made solely for the purpose of dividend, capital gains or earning of interest without involvement in the actual management of the enterprise in which such investment is made. A portfolio investor lends his/her capital in order to get a return on it, but has no control over the use of capital. The investor is primarily attracted by the interest and exchange rates differentials.
} 
system fragility through asset price bubble. Foreign portfolio investment is short-term in nature and will remain in an economy only if the returns are consistent with expectations, or at least at a tolerable level; otherwise, the funds will be moved to a more profitable jurisdiction without prior notice. Its short-term nature appears to be the culprit for instability in the financial system as witnessed in Asia, Latin America and Russia (Henry, 2003).

The over-exposure of the Nigerian capital market to foreign portfolio investment fuelled the stock market crisis. The decision of most foreign investors in the Nigerian stock market to exit the market in order to service their facilities elsewhere resulted in a sudden burst in asset prices, and decline in the volume of market activities. Essentially, the forces of demand and supply drive asset prices in Nigeria, because of the presence of information asymmetry and myopic investors. Foreign investors with superior information exited the market at its prime, but when other investors tried exiting the market, supply was greater than demand and asset prices crashed. It is misleading, though not unusual for the CBN and Securities Exchange Commission (SEC) at that time, to believe that Nigerian financial system was insulated from the crisis, let alone voicing it out to investors.

Nigerian banks were grossly affected by the crisis for two cardinal reasons. First, the banks were involved in margin lending ${ }^{15}$ which exposed banks to the capital market. The decision to invest in the capital market was largely influenced by the 2005 CBN induced consolidation. The banks at that time had excess funds and desperately wanted to employ them profitably. This desperation largely influenced their decision to embark on certain investments like margin lending, rapid establishment of bank branches, financing of consumables in order to use-up such excess funds. Banks gave out loans to individuals and corporate entities to invest in the capital market, and when the bubble burst, they were left with a heap of non-performing loans. Second, Nigerian banks also invested in the gas and oil sector, generally considered to be risky, which fundamentally negates the core values of risk management. The slide in oil prices in the international market exposed the banks further to a high volume of delinquent loans (Sanusi, 2009b).

From the narratives, it is apparent that the causes of the global financial crisis differ among countries. While the causes of the crises in developed economies were asset securitization, financial liberalization, housing policy, low interest rates and the activities of rating agencies, the same could not be said of developing economies. The causes of the crises in developing economies such as Nigeria were purely regulatory failure ${ }^{16}$ and the undiversified nature of their economies. In view of the foregoing, the causes of the crisis were not for want of regulatory tools but the inability of regulatory authorities to effectively use the existing micro-prudential tools. The fact that the macro prudential policy is based on lessons learned from developed economies, indeed casts serious doubts on the suitability of the tools across all jurisdictions.

\section{MACRO PRUDENTIAL POLICY TOOLKIT: A REVIEW}

Before the 2007/2008 global financial crisis, there was a clear-cut division between monetary policy and micro prudential policy. The purpose of monetary policy tools is to ensure price stability as it affects real aggregates like inflation, output, interest rates, exchange rates, and employment. The transmission channels of monetary policy are not debatable among economists, as the object of controversy has been the most effective transmission channel. Micro-prudential policy on the other hand, ensures that financial institutions are properly managed and financially sound to weather any form of crisis. However, the causes, nature, duration and amplitude of the 2007/2008 financial crisis have compelled regulators to rethink financial system regulation. Kannan et al., (2012) captured the rethinking in regulation thus "the Great Recession has caused policymakers to rethink the appropriate policy toolkit to deal with vulnerabilities stemming from financial markets. Before the crisis, consensus was that responding directly to fluctuations in asset prices or other financial variables is potentially harmful due to the inherent difficulty in detecting asset price bubbles in real time ${ }^{17}$.

Financial regulators and policy makers, especially those from developed economies, consensually question the effectiveness and adequacy of traditional policies (monetary policy tools and micro-prudential policy ${ }^{18}$ ) in achieving financial system stability. In their opinion, what was missing in the pre-crisis regime was a holistic view on financial system (Weistroffer, 2012). Financial system regulators, mostly from developed economies, advocated for the urgent need to adopt a broad-based, robust and proactive policy that will ensure the stability of the entire financial system and not the health of individual institutions in the financial system.

Given the enormous economic cost of the 2007/2008 crisis and the need to adopt a robust and proactive regulatory framework in preventing financial system vulnerability, the group of twenty leading economies (G-20) mandated the Bank for International Settlement, Financial Stability Board and International Monetary Fund (at the meeting in Seoul in November 2010) ${ }^{19}$ to develop a coherent framework for mitigating systemic risk. The regulatory taxonomy known as

\footnotetext{
${ }^{15}$ During the National Assembly probe on the causes of the crisis, one of the bank's CEO confessed that as at time Nigerian banks ventured into margin lending, they had no understanding of the principles governing margin lending.

${ }^{16}$ For details on regulatory failure, see Sanusi (2010)

${ }^{17}$ For details on this view, See Bernanke and Gertler (2001)

${ }^{18}$ Micro-prudential policy is generally criticized based on the following; it focuses only on the health of an individual institution; views economic shocks as exogenous; and ignores the systemic importance of individual institutions such as size, degree of leverage and interconnectedness with the financial system (Bank for International Settlement, 2011).
}

${ }^{19}$ See paragraph 41 of the Seoul Summit document. 
macro prudential policy, ${ }^{20}$ which these institutions were expected to further develop, is a regulatory and supervisory tool of the financial system that focuses on system-wide risk, rather than the riskiness of individual financial institutions (Hahm et al., 2012).

This explains the plethora of interest and research on this subject (though most of the studies are not available yet because of publication lag) among policy makers, academia and financial system regulators. Several pioneer studies on macro prudential policy (Borio, 2009; Milne, 2009; G-30, 2010; BIS, 2010; IMF, 2011 and Bank of England, 2011) focused on the goals of macro prudential policy, rationale for policy intervention and the instruments, without defining the concept vis-a-vis financial instability. Few studies have however defined the concept as: “... a policy that uses primarily prudential tools to limit system or system-wide financial risk, thereby limiting the incidence of disruption in the provisions of key financial services that can have serious consequences for the real economy by; dampening the build-up of financial imbalances and building defences that contain the speed and sharpness of subsequent downswings and their effects on the economy; and identifying and addressing common exposures, risk concentrations linkages and interdependencies that are sources of contagion and spill over risks that may jeopardize the function of the system as a whole (Financial Stability Board, IMF and BIS, 2011) ${ }^{21}$...the use of prudential tools with explicit objectives of promoting the stability of the financial system as a whole, not necessarily the individual institutions with it (Clement, 2010), and ...prudential policies (policies for "safety and soundness) that are aimed at mitigating system risk...(Longworth, 2011).

These definitions were influenced by the underlying assumption that prudential supervisors should take a system-wide approach in their supervision by understanding that the activities of individual firms could trigger systemic risk. As such, the emphasis should not be on the health of individual institutions but on how their activities or behaviour could trigger wider-system risk (Ellis, 2012). The definition of macro prudential policy centres on four central tenets which include the objective (mitigating system-wide financial risk), the scope (the entire financial system and its connectivity with the real economy), set of instruments (prudential tools with holistic view) and governance (macro prudential authority) ${ }^{22}$.

The justification for macro prudential policy intervention is based on the theory that "financial institutions do not internalize the spillovers of their behaviour to the financial system as a whole and to the real economy". Schoemaker and Wierts (2011) clearly captured this by explicitly noting that "under-pricing of risk, herding behaviour and moral hazard in the presence of implicit safety nets can lead to the build-up of financial imbalances over time. When such imbalances unwind, shocks quickly propagate through the financial system due to its high degree of connectedness". To mitigate this kind of externalities on a system-wide basis, there is need for prudential regulation that is holistic, forward looking and equipped with robust toolkits.

Macro prudential policy is not designed for managing crisis but a subset of policies for preventing system-wide risk. Macro prudential policy is designed to address time dimension (evolution of system-wide risk over time) and cross-sectional dimension (the distribution of risk in the financial system at a given point in time) system-wide risk ${ }^{23}$. The time dimension of risk arises (pro-cyclicality) through changes in the values of assets and leverage. For example, if a bank targets a desired leverage ratio and increases it asset holding in response to the increase in asset value, and in the presence of common shocks, all financial institutions do the same, the increase in demand raises their prices, further fuelling the cycle and leading to general expansion of credit, which could make bank balance-sheet structure more vulnerable to shocks through a range of balance sheet mismatches and weaknesses. Claessens and Ghosh (2012) identified these to include leverage ratio, maturity mismatches and foreign exchange mismatches. The cross-sectional dimension of risk is based on the interconnectedness of financial institutions and market, which can propagate shock of an institution to the entire system. Balance sheet-linkages or financial institution exposure to a particular asset class could amplify the propagation of individual institution's shock to the entire financial institutions.

The time and cross-sectional dimensional shock facing the financial system has necessitated the development of macro prudential typology instruments that can effectively monitor the system-wide risks in both dimensions. Commendable achievement is made in this direction by International Monetary Fund, Bank for International Settlement, Financial System Stability, Bank of England and academia. The macro prudential policy are generally developed to achieve the following; avoiding systemic level of leverage; ensuring a degree of liquidity for well functioning market; preventing excessive credit extension; and regulating market activities that could pose system risk. The tools include countercyclical capital buffer, sectorial capital requirement (variable risk weight), maximum leverage ratio, time-varying provisioning practices, restriction on distribution (profits paid to shareholders as dividend and staff as discretionary remuneration), time varying liquidity

\footnotetext{
${ }^{20}$ For the history of macro prudential policy, see Galati and Moessner (2011)

${ }^{21}$ Financial Stability Board, International Monetary Fund and Bank for International Settlement (2011) was an update on the macro prudential policy which was presented to the g-20 Finance Ministers and Central Bank Governors by the three institutions.

${ }^{22}$ For details see FSS, IMF and BIS (2011).

${ }^{23}$ According to FSS, IMF and BIS (2011), the key issue in time dimension is to mitigate or dampen financial procyclicality , i.e., how financial system-wide risk can be amplified by interactions within the financial system and between the financial system and the real economy, sometimes leading to financial crisis. The key issues in the cross-sectional dimension is to reduce systemic risk concentrations, which arise from similar exposures across financial institutions (from assets, liabilities, dependence on common services) or because of direct balance-linkage between them (counterparty risk).
} 
buffer, loan to value to income restriction, managing requirements on secured financing and derivative transactions, use of central counterparty, design and use of trading venues and disclosure requirements (Bank of England, 2011). ${ }^{24}$

Though, macro prudential tools are viewed to be different from micro prudential tools in terms of scope (macro prudential policy strives to ensure the stability of the entire financial system while micro prudential policy strives to ensure the stability of individual institutions), sources of economic shocks (macro prudential policy views economic shocks as internal to the financial system while micro prudential policy views it as external), and systemic importance of institutions (micro prudential policy ignores the systematic importance of individual institutions such as size, degree of leverage and interconnectedness with the financial system while macro prudential policy considers the systemic behaviour in the management of the system as a whole), the consensus is that the macro prudential policy exists only to compliment micro prudential policy, and cannot be a substitute for sound micro prudential and economic policies. Governments of developed nations have shown their countries' direction as it relates to the new prudential policy. Up till now, little is known about the direction of African governments and African Central Banks in terms of whether they are adopting some of the tools developed based on lessons learned from developed economies, irrespective of differences in the structure of the economies and financial systems, or they are still gathering momentum to develop tools that are adaptable to their institutional species, despite the public knowledge that some of the newly recommended macro prudential tools were already in existence in emerging economies as micro prudential tools ${ }^{25}$

\section{THE CHALLENGES OF IMPLEMENTING MACRO PRUDENTIAL POLICY IN DEVELOPING ECONOMIES}

The major challenges developing economies (especially African countries) are grappling with are inflation and critical regulatory gap. Financial stability without economic stability has been described as "the stability of the graveyard" ${ }^{\text {"26 }}$. For instance, inflation in Nigeria as at $31^{\text {st }}$ December, 2012 was $12.4 \%$, industries generate their power, absence of security of lives and property, poor road network, multiple taxation and fiscal indiscipline abound. Can banks in such economies advance credit to the real sector? Given the cost of doing business, what will be the expected return on investment and at what rate can firms actually borrow? How can these challenges be resolved, with macro prudential or micro prudential policies? One of the central tenets of this paper is that developing economies cannot achieve financial stability without a favourable macroeconomic environment which is a pre-cursor of financial stability.

The extrapolation of prudential tools from developed economies requires serious caution by developing economies because of dissimilarities in economic structure, financial system, governance structure and causes of systemic risk. For instance, low information disclosure, less developed capital market, narrow investor base, market imperfection and inadequate financial instruments are the characteristics of developing economies' financial markets which amplify shocks and erode investors' confidence. How can macro prudential toolkits mitigate these risks? One tool that has received overwhelming approval from the international panel of regulators that meets in Basel (Basel 111) and macro prudential experts is the countercyclical capital buffer. The underlying assumption is that banks build-up more risk in good times when lending is increasing quickly, as such, there should be more capital in the system to deal with the risk in bad times (Aikman, et al., 2012). Countercyclical buffer is expected to dampen the amplitude of cycles and enhance banking sector resilience.

As with most theories, the ability of the countercyclical buffer to dampen the amplitude of cycles will depend on inflationary pressure and business cycle (period of economic boom and economic bust) of any economy. The presence of spiralling inflation deters the ability of banks in building-up capital to deal with shocks in bad times, especially if the boom period is prolonged. In an inflationary economy, the value of the countercyclical buffer erodes with prolonged business cycle making the financial system vulnerable as banks will have limited capital to cushion the shocks. The presence of spiralling inflation will also have multiple negative effects on developing economies. First, the introduction of countercyclical buffer will astronomically increase cost of funding in an economy that is already starved of funds and will hurt economic growth. Second, because of the fear of eroding value of money, banks will prefer to lend short in their desperate ploy to remain profitable which will create a critical gap in the long-term end of the market or make the market atrophied in nature. Banks may be compelled to involve in regulatory arbitrage, that is, pushing their lending to other jurisdictions without similar requirements since the switching-on of the countercyclical buffer is country dependent ${ }^{27}$.

\footnotetext{
${ }^{24}$ For details on macro prudential policy tools (See G-30, 2010; Milne, 2010; Bank of England 2011; Weistroffer, 2012; FSS, IMF and BIS 2011 and Galati and Moessner (2011).

${ }^{25}$ Borio and Shim (2007), McCauley (2009), CGFS (2010), Moreno (2011) and Claessens and Gosh (2012) documented extensive evidence on the existence of some of the tools in developing economies.

${ }^{26}$ See Turner (2012)

${ }^{27}$ The presence of Nigerian banks in other West African countries could give them the incentive to embark on this kind of regulatory arbitrage. Though, the draftsmen tried mitigating this kind of arbitrage by suggesting that once the home country applies any buffer rate, the government where the foreign branch is domiciled should apply a higher rate. However, this will depend on whether the stage of the business cycle of the economies, even when in the same stage, there might be lags in the implementation of the requirement between the two countries.
} 
Another key amplification of financial fragility in developing economies is capital flow, as it could worsen macroeconomic vulnerabilities and pose daunting challenges to financial stability. While capital flow could exacerbate financial system fragility when intermediated through banks, they could prove even more fatal to financial system stability when in the form of portfolio investment through asset pricing bubble. Capital flow was the major cause of the crisis in Nigeria and is currently building-up again. The volume of 'hot money in the Nigerian financial system is estimated at $\$ 12 \mathrm{bn}$ as at March, 2013 (Chima, 2013). Given the potential risk of capital flow in developing economies, what macro prudential tools are available to mitigate this risk? Extensive theoretical and empirical literatures exist on the effective mechanisms for managing capital flow on economic wide basis ${ }^{28}$, but with inconclusive results. Scholars could not reach a consensus on the best tool or set of tools for managing capital flow, but argue that appropriate policies will depend on causes of the capital flow, the nature (temporary or permanent) and the prevailing macroeconomic conditions.

Institutional peculiarity is the nucleus for determining the optimal combination of policies. Claessens and Gosh (2012) demonstrated the limitations of using sterilized intervention mechanism as "sterilized intervention may prove fiscally too costly and ineffective, especially if the capital flows are largely driven by global liquidity and short-term interest differentials, as higher interest rates would only serve to attract more inflows. While tightening fiscal policy could be beneficial under circumstances, this may prove difficult in practice since emerging markets tend to have few automatic stabilizers and fiscal policies operate in lag". The onus is on developing economies to develop tool(s) that can determine each country's absorptive capacity in order not to promote a build-up to risk ${ }^{29}$. These could take the form of explicit or implicit capital restrictions ${ }^{30}$ or capital controls.

The undiversified structure of developing economies is another cause of the crisis and avenue to external shocks. Nigeria for instance, is still dependent on crude oil, and the slide of crude oil prices in the international market adversely affected the ability of the government to honour her financial obligations (sovereign debt default). This has far reaching implications in some developing economies where public fund has crowded out private fund. Developing economies' balance of payment is predominantly dependent on commodity prices, and the higher the commodity exposure, the higher the external shock. What can macro prudential policy do in this regard? The only way to mitigate this kind of systemic risk is to diversify the economy; and while this is entirely outside the realm of macro prudential policy, yet it is one of the causes of the 2007/2008 global financial crisis in developing economies. The time is ripe for developing economies, especially African governments, to rethink the dependence of their economies on commodity exports. This is a challenge that requires urgent solution despite the level of financial integration to the financial system.

Is the over-exposure of the Nigerian banking sector to the capital market through margin lending and oil and gas sector a case of non-availability of macro prudential policy or failure of effective use the micro prudential tools? Would the introduction countercyclical buffer have mitigated failure in corporate governance, reckless abandonment of core value of risk management in the banking system, unstructured governance and weakness in Central Bank of Nigeria, critical gap in regulation and regulatory framework, unfavourable macroeconomic environment among others ${ }^{31}$ ? The excess-exposure of the banking system to the capital market and oil and gas were issues that are avowedly micro prudential and anybody would have expected regulators of the financial system to mitigate them as they were gathering momentum.

Failure of the Central Bank of Nigeria to promote price and financial system stability has influenced some scholars to propose the separation of price stability mandate from financial stability mandate; thus, while the first is domiciled with CBN, the government should create a new institution to undertake the later mandate (Ogowo and Uche, 2006) ${ }^{32}$ Additionally, there could be a micro prudential guideline that places restriction on the individual bank's maximum exposure to risky sectors such as the margin lending and investment in oil and gas sector. Such restriction could be $10 \%$ of shareholders' fund unimpaired by loss, which would not need macro prudential authorities to raise any form of alarm or the giving of one year prior notice as in the countercyclical buffer recommendation. Such alarm and long notice (one year) could trigger bank run, discourage bank habit or give banks the inventive to circumvent the regulation, ultimately crystallising into banking crisis.

\title{
5. CONCLUSION
}

\footnotetext{
${ }^{28}$ The sequential decision-tree type approach is generally recommended.

${ }^{29}$ Asia has risen to this challenge by developing balance of payments risk warning system, to assess the trend and the risks of crossborder capital movement and contingency plans to deal with possible extreme circumstance (see Moreno (2011) for details).
}

\begin{abstract}
${ }^{30}$ According to Moreno (2011), "while currency borrowing has generally been liberalised, a number of [emerging economies] still impose restrictions. For example, in the 2000s, Argentina has maintained a number of controls on foreign currency borrowing, including minimum holding periods and unremunerated reserve requirements. Similar measures have been implemented in Columbia and had been used in the past in Chile. India traditionally has maintained restrictions that seek to encourage FDI and limit external borrowing, particularly shortterm....Brazilian government reintroduced a financial transaction tax on foreign capital investment, to apply to local bond and equities (but not foreign direct investment), setting it at $2 \%$.
\end{abstract}

${ }^{31}$ For details on the causes of bank distress see Sanusi (2010).

${ }^{32}$ Ogowo and Uche (2006) argue that the price and financial stability mandates should be separated in line with practice in economies with high bank failures (such as Japan) or history of high inflation (such as Germany). 
The paper examined how the 2007/2008 global financial crisis induced financial system regulators to adopt the macro prudential policy. The development of macro prudential toolkits was believed to be based on lessons learned from the crisis and the inadequacy of micro prudential policy to prevent the crisis. The universality or adaptability of the macro prudential policy toolkit in developing economies is currently in question. This is because of dissimilarities in the structure of the economies, the causes of the crisis and market development. Specifically, the causes of the crisis in developing economies is not based on deficiencies in regulatory tools, but purely, failure in the effective use of micro prudential tools, structure of the economy (undiversified nature of the economy) and unfavourable macroeconomic environment.

Priorities of governments of developing economies should not be on the adoption of macro prudential policy, but to advance policies that will prevent the economies from relapsing into further crisis. In this light, it is important for the government to earnestly pursue a favourable macroeconomic environment by promoting price stability and infrastructural financing. It is important also to diversify the economy from commodity export, which is a major source of externalities, and restrict capital flow through capital control or capital restriction.

\section{REFERENCES}

[1] Adam, C. and Park, D. (2009). Causes and consequence of global imbalances: Perspective from Developing Asia, Asia Development Review, 26(1), 19-47

[2] Aikman, D., Nelson, N. and Tanaka, M. (2012). Reputation, risk taking and macro prudential policy, Bank of England Working Paper No.462, October.

[3] Arnold, B., Borio, C., Ellis, L. and Moshirian, F. (2012), System risk, macro prudential policy frameworks monitoring financial systems and the evolution of capital adequacy, Journal of Banking and Finance, Retrieved from http://dx.doi.org/10.1016/j.jbankfin.2012.07.023

[4] Asia Development Bank (2009). Global financial crisis and proposed ADB Response", Asia Development Bank Publication.

[5] Bank for International Settlement (2010). Macro prudential instruments and frameworks: A stocktaking of issues and experiences, CGFS Papers No.38, Basel.

[6] Bank of England (2011). Instruments of Macro prudential policy, A Discussion Paper, London.

[7] Bernanke, B.S. and Gertler, M. (2001). Should central banks respond to movements in asset prices? American Economic Review Paper Papers and Proceedings 91, 253-257

[8] Borio, C. (2009). Implementing the macro prudential approach to financial regulation and supervision, Banque de France Financial Stability Review 13, 31-41.

[9] Borio, C. and Shim, I. (2007). What can macro-prudential policy do to support monetary policy", BIS Working Paper No. 22.

[10] Chima, O. (2013, March 18). Managing \$12bn "hot money" tops agenda as MPC meets, Thisday Daily Newspaper, Retrieved from http://www.thisdaylive.com/articles/managing-12bn-hot-money-tops-agenda-as-mpcmeets/142474/

[11] Chossudovsky, M. (2009). Global financial meltdown: The African perspective", Retrieved from http://www.global research.ca access August 2009

[12] Claessens, S. and Ghosh, S.R. (2012). Macro-prudential policies: Lessons for and from emerging markets, Paper Prepared for the East-West Centre and the Korea Development Institute Conference on Financial Regulation on International Capital Flows and Exchange Rates, July 19-20, 2012, Hawaii.

[13] Clement, P. (2010). The term 'macro prudential policy': Origins and evolutions, Bank for International Settlement Quarterly Review

[14] Committee on the Global Financial System (2010). Macro prudential instruments and frameworks, CGFS Papers No. 36, March.

[15] Ekholm, K. (2012). Macro prudential policy and clear communication contribute to financial stability", Speech Delivered to the Swedish Bankers' Association, Stocholm, March 30.

[16] Ellis, L. (2012). Macroprudential plocy: A suite of tools or a state of the mind? A Speech Delivered During Paul Woolley Centre for Capital Market Dysfunctionality Annual Conference, October 11, 2012, Sydney.

[17] Financial Stability Board, International Monetary Fund and Bank for International Settlement (2011). Macro prudential policy tools and frameworks: Update to G20 Finance Ministers and Central Bank Governors, Retrieved from

[18] Galati, G. and Moessner, R. (2011). Macro prudential policy - A literature review, Bank for International Settlements Monetary and Economic Department Working Papers No. 337, Basel Switzerland, 1-37.

[19] Goodhart, C.A.E. (2011). The Macro prudential authority, powers, scope and accountability, OECD Journal: Financial Trends, 2: 1-26.

[20] Group of Thirty (2010), Enhancing financial stability and resilience: Macro prudential policy, tools, and system for the future, Working Paper on Macro prudential Policy, Washington D.C.

[21] Gupta, V., Mittal, R.K. and Bhalla, V.K. (2010). Role of credit rating agencies in financial markets", Journal of Development and Agricultural Economics, 2(7): 268-276.

[22] Hahm, J., Mishkin, F.S., Shin, H.S. and Shin, K. (2012). Macro prudential policies in open emerging economies, Asia Economic Conference Paper on Asia's Role in the Post-Crisis Global Econonmy, 63-114

[23] Hampel, B., Schenk, M. and Rick, S. (2008). The US mortgage crisis: Causes effects and outlook, Credit Union National Association Policy Analysis Division Publication.

[24] Henry, P. (2003). Capital-account liberalization, the cost of capital and economic growth, American Economic Review, 93(2): 91-96.

[25] International Monetary Fund (2011). Macro prudential policy: An organizing framework, Washington D.C. 
[26] International Monetary Fund (2009). Global economic policies and prospects, Group of Twenty Meeting of the Ministers and Central Bank Governors, March 13-14, 2009, London, U.K

[27] International Monetary Fund (1993). Balance of Payments Manual in Knill, M.A. (2005), "Taking the good with the bad: Volatility of foreign portfolio investment and the financial constraint of small firms," World Bank Policy Research Working Paper No. 3797

[28] Kannan, P., Rabanal, P. and Scoth, A.M. (2012). Monetary and macro prudential policy rules in a model with house price booms, The B.E. Journal Macroeconomics Contributions, 12(1): 1690 -2268, DOI: 10.1515/19351690.2268

[29] Longworth, D. (2011), A survey of macro prudential policy issues, Retrieved from http://qed.econ.queensu.ca/paper/A\%20Survey\%20of\%20Macroprudential\%20Policy\%20lssues\%20Queens.pdf

[30] McCauley, R. (2009), Macro prudential policy in emerging markets, Paper Presented at the Central Bank of Nigeria's $50^{\text {th }}$ Anniversary International Conference on Central banking, financial system stability and growth, Abuja, 4-9 May.

[31] Mckinnon, R.1. (1973), Money and Capital in Economic Development, Watsontown, DC. Broking Institutions.

[32] Milne, A. (2010), Macro prudential policy: An assessment, CESifo DICE Report, 28-33.

[33] Milne, A. (2009). Macro prudential Policy: What can it really achieve? Oxford journal of Economic Policy 25(4): 1 22

[34] Moreno, R. (2011). Policymaking from a "macro prudential" perspective in emerging market economies, BIS Working Paper No.336, January.

[35] Ogowo, T.I. and Uche, C. (2006). (Mis)using bank share capital as a regulatory tool to force bank consolidations in Nigeria, Journal of African Law, 50(2): 161-189.

[36] Sanusi, L.S. (2009a). Developments in the banking system in Nigeria, Retrieved from http://www.cenbank.org

[37] Sanusi, L.S. (2009b). An assessment of current development in the Nigerian economy and the Central Bank of Nigeria (CBN) Policy Action Retrieved from http://www.cenbank.org

[38] Sanusi L.S. (2010), The Nigerian industry: What went wrong and the way forward, Lecture delivered at the Convocation Square, Bayero University, Kano, on Friday 26 February, 2010 to mark the Annual Convocation Ceremony of the University

[39] Schoemaker, D. and Wierts, P. (2011). Macro prudential policy: The need for a coherent framework, Duisenberg School of Finance Policy Paper Series No.13, 1-19.

[40] Shaw, E.S. (1973), Financial Deepings in Economic Development, New York: Oxford University Press.

[41] Turner, L. (2012). Macro-prudential policy in deflationary times, A Speech Delivered during the Financial Policy Committee Regional Visit to Manchester, July 20.

[42] Uche, C.U. (2009), Rethinking regulation for financial system stability in Africa", Paper Presented at the International Conference on Central Banking Financial Stability and Growth, Organized by the Central Bank of Nigeria to commemorate fifty years of Central Banking in Nigeria, Abuja.

[43] Uche, C.U. (2001), The adoption of universal banking in Nigeria, Butterworths Journal of International Banking and Financial Law, 16(9): 421-428.

[44] Ujunwa, A., Salami, P.O and Umar, H.A. (2011). The global financial crisis: Realities and implication for the Nigerian capital market, American Journal of Social and Management Sciences, 2(3): 341-347

[45] Weistroffer, C. (2012), Macro prudential supervision: In search for an appropriate response to systemic risk, Deutsche Bank Current Issues on Global Financial Markets, May. 